\title{
Microcystin-LR: How it affects the cardio-respiratory responses to hypoxia in Nile tilapia, Oreochromis niloticus
}

\author{
Nathan Dias Martins ${ }^{a}$, Wilson Alves Colvara ${ }^{b}$, Francisco Tadeu Rantin ${ }^{a}$, Ana Lúcia Kalinin ${ }^{\mathrm{a}, *}$ \\ ${ }^{a}$ Department of Physiological Sciences, Federal University of São Carlos - UFSCar, Via Washington Luís, Km 235, 13565-905 São Carlos, São Paulo, Brazil \\ ${ }^{\mathrm{b}}$ Institute of Oceanography, Cyanobacterial Research Unit, Federal University of Rio Grande - FURG, Avenida Italia, Km 8, $96201-900$ Rio Grande, Rio Grande do Sul, Brazil
}

\section{A R T I C L E I N F O}

\section{Article history:}

Received 24 August 2010

Received in revised form 31 January 2011

Accepted 5 February 2011

Available online 5 March 2011

\section{Keywords:}

Microcystin-LR

Hypoxia

Metabolic rate

Ventilatory parameters

Heart rate

Oreochromis niloticus

\begin{abstract}
A B S T R A C T
The effects of microcystin on the cardio-respiratory function of Nile tilapia were analyzed $48 \mathrm{~h}$ after intraperitoneal injection of microcystin-LR (MC-LR - $100 \mu \mathrm{g} \mathrm{kg}^{-1}$ body weight). Exposure to MC-LR induced significant reduction in metabolic rate $\left(\mathrm{VO}_{2}\right)$ and increase in the critical $\mathrm{O}_{2}$ tension $\left(\mathrm{P}_{\mathrm{C}} \mathrm{O}_{2}\right)$ in relation to the control group. Gill ventilation $\left(\dot{V}_{\mathrm{G}}\right)$ and ventilatory tidal volume $\left(V_{\mathrm{T}}\right)$ were considerably lower in fish exposed to MC-LR, probably due to an alteration in the homeostatic mechanisms, impairing the regular respiratory response of this species to environmental hypoxia. The ability to maintain the $\mathrm{O}_{2}$ extraction from the ventilatory current $\left(\mathrm{EO}_{2}\right)$ during severe hypoxia was also significantly reduced in fish exposed to MC-LR exposure. Control fish displayed the characteristic reflex bradycardia in response to hypoxia. However, when compared to the control group, fish exposed to MC-LR presented significantly lower heart rate $\left(f_{\mathrm{H}}\right)$ in normoxia and in all experimental hypoxic levels, probably due to a direct effect of this toxin on the cardiac tissue.
\end{abstract}

(c) 2011 Elsevier Ltd. All rights reserved.

\section{Introduction}

Under favorable conditions, cyanobacteria can form large superficial masses of green color called blooms (Reynolds, 1984). In general, $50-75 \%$ of cyanobacterial blooms produce toxins, with a possible occurrence of more than one type of toxin within the same bloom. The microcystins (MC) are the most common toxins found in freshwater blooms (Carmichael, 1994; Kondo et al., 2002), with dissolved concentrations varying from traces up to $25000 \mu \mathrm{g} \mathrm{L}^{-1}$ or higher, immediately after the collapse of a highly toxic bloom (Chorus and Bartram, 1999; Amado and Monserrat, 2010). Despite the occurrence of more than 70 variants of MC (Fastner et al., 2002), microcystin-LR (MC-LR) stands out for its high frequency in natural environments and the large volume of studies on its structure and mechanisms of action (de Figueiredo et al., 2004).

The uptake of these toxins by the cells seems to involve an active transport system, known as multi-specific bile acids transportation system (Eriksson et al., 1990) involving organic anion transporting polypeptides (OATP). The MC acts in the inhibition of protein phosphatases, especially types 1 and 2A (PP1 and PP2A) (Toivola and Eriksson, 1999; Guzman et al., 2003). The inhibition of these phosphatases leads to a state of protein hyperphosphorylation that regulate the dynamic formation of the

\footnotetext{
* Corresponding author. Tel.: +55 16 33519775; fax: +55 1633518401 .

E-mail address: akalinin@ufscar.br (A.L. Kalinin).
}

cytoskeleton, resulting in the disintegration of cell structure, mainly in hepatocytes (Carmichael, 1994). Besides the inhibition of phosphatases, microcystins can also affect the DNA repair systems and expression of genes (Ariza et al., 1996; Douglas et al., 2001), being able to interact with the mitochondria of animal tissues, causing oxidative stress and apoptosis (Prieto et al., 2009).

Apart from released toxins, cyanobacterial blooms can degrade water quality, causing exhaustion of dissolved oxygen (Brownlee et al., 2005) and a sharp increase in nutrients (Buryskova et al., 2006). In this context, Zhang et al. (2011) showed a strong correlation between $\mathrm{MC}$ and dissolved $\mathrm{O}_{2}$ in Lake Taihu, China. The authors showed that the $\mathrm{O}_{2}$ concentration of $10.24 \pm 1.25 \mathrm{mg} \mathrm{L}^{-1}$ and MCs concentration of $0.09 \pm 0.09 \mu \mathrm{g} \mathrm{L}^{-1}$ found before cyanobacterial blooms changed to $7.03 \pm 2.29 \mathrm{mg} \mathrm{L}^{-1}$ and $0.91 \pm 0.70 \mu \mathrm{g} \mathrm{L}^{-1}$, respectively, during the blooms.

Several studies in teleost fish have demonstrated the effects of microcystin-LR and its variants on organs such as liver, gills, kidneys, heart, among others (Carbis et al., 1997; Best et al., 2001; Zhang et al., 2007). Damages in hepatopancreas and kidney cells (Fischer and Dietrich, 2000), cardiac myopathy (Atencio et al., 2008), gill necrosis, folded lamellar tips and mild epithelial ballooning (Carbis et al., 1997), anemia (Katharios et al., 2002; Zhang et al., 2007), and the occurrence of oxidative stress and lipoperoxidation (Prieto et al., 2006) are some of these changes.

Although MC-LR is the most studied variant among the microcystins, there is a dearth of studies linking fish exposure to MC-LR with changes in the in vivo cardio-respiratory function. 
Thus, the main goal of this study was to analyze the effect of MC-LR on respiratory and cardiac function of Nile tilapia, Oreochromis niloticus.

\section{Materials and methods}

This study was conducted in accordance with the Brazilian legislation on animal experimentation and duly approved by the Ethics in Animal Experimentation Committee/Federal University of São Carlos, Brazil.

\subsection{Animals}

Specimens of 0 . niloticus ( $\mathrm{Wt}=175 \pm 37 \mathrm{~g}$ ) were obtained from the fish farm Águas Claras, Mococa, São Paulo State, Brazil. Fish were acclimated for $30 \mathrm{~d}$ prior to experimentation in $1000 \mathrm{~L}$ holding tanks equipped with a continuous supply of well-aerated and dechlorinated water, at $25 \pm 2{ }^{\circ} \mathrm{C}$ and under natural photoperiod ( $\sim 12 \mathrm{~h}: 12 \mathrm{~h})$. The physical and chemical parameters were kept nearly constant: $\mathrm{pH}$ 6.7-7.3, DO $6.0-7.3 \mathrm{mg} \mathrm{L}^{-1}$, hardness $48-$ $53 \mathrm{mg} \mathrm{L}^{-1}$ (as $\mathrm{CaCO}_{3}$ ), alkalinity $40-43 \mathrm{mg} \mathrm{L}^{-1}$ (as $\mathrm{CaCO}_{3}$ ), ammonium $0.1 \mathrm{mg} \mathrm{L}^{-1}$; chloride $42 \mathrm{mg} \mathrm{L}^{-1}$, and conductivity $110 \mu \mathrm{sm}^{-1}$. During this period, fish were fed ad libitum with commercial fish pellets.

\subsection{Experimental design}

After acclimation, specimens of 0 . niloticus were divided into two groups: Control fish (Ctrl, $n=8$ ) and fish exposed to the toxin (Mcys, $n=8)$. The Mcys group received an intraperitoneal injection $(0.5 \mathrm{~mL}$ of $0.9 \%$ saline) containing the purified form of the toxin microcystinLR at a concentration of $100 \mu \mathrm{g} \mathrm{kg}^{-1}$ body weight. The control group (Ctrl) received only saline injections $(0.5 \mathrm{~mL}$ of $0.9 \%$ saline). Measurements of respiratory and cardiac parameters were made $48 \mathrm{~h}$ after injections. The purified MC-LR (Microcystis aeruginosa) was provided by the Cyanobacterial Research Unit of the Federal University of Rio Grande - FURG, Rio Grande do Sul State, Brazil.

Most studies on the acute lethality of MCs in fish have utilized intraperitoneal injections of extracted MCs to determine the dose that is lethal to half the test population $\left(\mathrm{LD}_{50}\right)$, and the reported values range from 20 to $1500 \mu \mathrm{g} \mathrm{kg}^{-1}$ body weight (Malbrouck and Kestemont, 2006). Prieto et al. (2006) and Atencio et al. (2008) submitted specimens of Oreochromis sp. to an intraperitoneal single dose of $500 \mu \mathrm{g} \mathrm{kg}^{-1}$ MC-LR and reported acute toxic effects without mortality. Thus, the concentration of $100 \mu \mathrm{g} \mathrm{kg}^{-1}$ MC-LR was selected in the present study to avoid acute toxic effects and possible death.

\subsection{Surgical procedures}

Fish were immersed in a benzocaine solution ( $1 \mathrm{~g}$ of benzocaine dissolved in $0.1 \mathrm{~L}$ of $99 \%$ ethanol and diluted in $10 \mathrm{~L}$ of water). This provided a level of anesthesia which still allowed spontaneous breathing. To monitor the respiratory frequency $\left(f_{\mathrm{R}}\right)$ and measure the $\mathrm{O}_{2}$ tensions of the inspired water $\left(\mathrm{P}_{\mathrm{i}} \mathrm{O}_{2}\right)$ a PE-100 catheter was inserted dorsally into the buccal cavity close to the mouth. Furthermore, the border of both opercular cleithra were cannulated (PE-50 catheter) to measure the $\mathrm{O}_{2}$ tensions of the expired water $\left(\mathrm{PeO}_{2}\right)$. Two ECG electrodes were placed in a ventral position, the first (positive) between the gills and the heart, and the second (negative) in a ventral position close to the pelvic fins. A reference electrode was located in the water of the experimental chamber. This preparation allowed for electrocardiographic (ECG) recordings of the first diagonal branch (D1) lead. After surgery, the fish were placed into a respirometer and, subsequently, into the experimental chamber to recover for $24 \mathrm{~h}$ in normoxic water $(140 \mathrm{~mm} \mathrm{Hg})$ at
$25 \pm 1{ }^{\circ} \mathrm{C}$ (temperature for all experiments). Meanwhile, disturbances were avoided to obtain resting control values.

\subsection{Responses to hypoxia}

The weight-specific oxygen uptake, or metabolic rate $\left(\dot{\mathrm{VO}}_{2}-\mathrm{mL} \mathrm{O}_{2} \mathrm{~kg}^{-1} \mathrm{~h}^{-1}\right.$ ), was measured by flow-through respirometry (Kalinin et al., 1999; Thomaz et al., 2009). The fish was housed in an open flow-through respirometer while ingoing and outgoing $\mathrm{PO}_{2}$ $\left(\mathrm{P}_{\text {in }} \mathrm{O}_{2}\right.$ and $\left.\mathrm{P}_{\text {out }} \mathrm{O}_{2}\right)$ were continuously recorded. Water was siphoned, via polyethylene catheters, to $\mathrm{O}_{2}$ electrodes (FAC001- $\mathrm{O}_{2}$, FAC-São Carlos, SP, Brazil) housed in temperature controlled cuvettes and connected to a FAC-204AO 2 Analyzer. Measurements were performed for various $\mathrm{PO}_{2}$ and each tension was maintained for $1 \mathrm{~h}$ before measurements were taken. $\mathrm{VO}_{2}$ was calculated as:

$\dot{\mathrm{VO}}_{2}=\left[\left(\mathrm{P}_{\text {in }} \mathrm{O}_{2}-\mathrm{P}_{\text {out }} \mathrm{O}_{2}\right) \cdot \alpha \mathrm{O}_{2} \cdot \dot{V}_{\mathrm{R}}\right] / \mathrm{Wt}$

where $\dot{V}_{\mathrm{R}}$ represents the constant water flow through the respirometer $\left(\mathrm{L} \mathrm{h}^{-1}\right), \alpha \mathrm{O}_{2}$ denotes the solubility coefficient for $\mathrm{O}_{2}$ in water $\left(\mathrm{mLO}_{2} \mathrm{~L}^{-1} \mathrm{~mm} \mathrm{Hg}^{-1}\right)$ and $\mathrm{Wt}$ the body mass $(\mathrm{kg})$. The flow through the respirometer was adjusted according to Steffensen (1989) to ascertain a steady-state condition in less than $30 \mathrm{~min}$.

The critical $\mathrm{O}_{2}$ tension $\left(\mathrm{P}_{\mathrm{c}} \mathrm{O}_{2}\right)$ was determined graphically. In short, a line parallel to the abscissa axis was set in the $\mathrm{P}_{\mathrm{in}} \mathrm{O}_{2}$ interval in which $\mathrm{VO}_{2}$ values were maintained constant $(p<0.05)$, and a linear regression line was fitted through the points located in lower $\mathrm{P}_{\mathrm{in}} \mathrm{O}_{2}$ values. The intersection of these two lines determined a set point that, projected onto the abscissa axis, allowed the estimation of $\mathrm{P}_{\mathrm{c}} \mathrm{O}_{2}$.

Gill ventilation $\left(\dot{V}_{\mathrm{G}}-\mathrm{mLH}_{2} \mathrm{O} \mathrm{kg}{ }^{-1} \mathrm{~min}^{-1}\right)$ was measured according to the method of Hughes et al. (1983). Continuous measurements of the inspired $\left(\mathrm{P}_{\mathrm{i}} \mathrm{O}_{2}\right)$ and expired $\left(\mathrm{P}_{\mathrm{e}} \mathrm{O}_{2}\right)$ water $\mathrm{O}_{2}$ tensions were taken by means of the implanted buccal and opercular PE catheters, respectively. The $\dot{V}_{\mathrm{G}}$ was calculated as:

$\dot{V}_{\mathrm{G}}=\left[\left(\mathrm{P}_{\text {in }} \mathrm{O}_{2}-\mathrm{P}_{\text {out }} \mathrm{O}_{2} / \mathrm{P}_{\mathrm{i}} \mathrm{O}_{2}-\mathrm{P}_{\mathrm{e}} \mathrm{O}_{2}\right) \cdot \dot{V}_{\mathrm{R}}\right] / \mathrm{Wt}$

Respiratory frequency $\left(f_{\mathrm{R}}\right.$ - breaths $\left.\mathrm{min}^{-1}\right)$ was measured from the buccal pressure variation. The buccal PE catheter was connected to a pressure transducer coupled to an amplifier of a PowerLab 8/30 data-acquisition system (ADInstruments, Australia).

The ventilatory tidal volume $\left(V_{\mathrm{T}}-\mathrm{mLH}_{2} \mathrm{O} \mathrm{kg}{ }^{-1}\right.$ breath $\left.{ }^{-1}\right)$ was calculated by dividing the gill ventilation by the respiratory frequency $\left(\dot{V}_{\mathrm{G}} / f_{\mathrm{R}}\right)$. The $\mathrm{O}_{2}$ extraction from the ventilatory current by the gills $\left(\mathrm{EO}_{2} \%\right)$ was calculated as:

$\mathrm{EO}_{2}=\left[\left(\mathrm{P}_{\mathrm{i}} \mathrm{O}_{2}-\mathrm{P}_{\mathrm{e}} \mathrm{O}_{2}\right) / \mathrm{PiO}_{2}\right] \cdot 100$

To obtain the heart rate $\left(f_{\mathrm{H}}-\mathrm{bpm}\right)$, ECG electrodes were connected to a bio-amplifier of the same data-acquisition system as described above.

After recover from surgery, the normoxic $\left(\mathrm{P}_{\text {in }} \mathrm{O}_{2}=140 \mathrm{~mm} \mathrm{Hg}\right)$ control values were measured and, subsequently, the $\mathrm{P}_{\mathrm{in}} \mathrm{O}_{2}$ was decrementally reduced to $120,100,80,60,40,20$ and $10 \mathrm{~mm} \mathrm{Hg}$. Each $\mathrm{O}_{2}$ tension was maintained for $30 \mathrm{~min}$ with an additional 15 min period for measurements. Normoxia was maintained by bubbling the water with compressed atmospheric air. Hypoxic levels were achieved and kept constant by dispersing pure $\mathrm{N}_{2}$ in appropriate volumes into the water of the experimental tank (Thomaz et al., 2009). All of the above variables were simultaneously measured for the same individual, and each fish was always subjected to the complete experimental sequence.

\subsection{Statistical analysis}

Results are presented as means $\pm \mathrm{SD}$. Analysis of variance (ANOVA), complemented by Tukey-Kramer multiple comparisons 
was used to check the possible existence of significant variations between the values obtained at different $\mathrm{O}_{2}$ tensions for the same experimental group. The Mann-Whitney test was performed to verify the occurrence of possible differences between corresponding points in both groups. Statistical differences were considered at 5\% significance (Graphpad Instat, version 3.06).

\section{Results}

Fig. 1 shows the effects of graded hypoxia on metabolic rate $\left(\mathrm{VO}_{2}\right)$ and critical $\mathrm{O}_{2}$ tension $\left(\mathrm{P}_{\mathrm{C}} \mathrm{O}_{2}\right)$ in both experimental groups. The $\dot{\mathrm{VO}}_{2}$ of Ctrl group remained nearly constant until a $\mathrm{PO}_{2}$ of $20 \mathrm{~mm} \mathrm{Hg}$. Only during the lowest $\mathrm{PO}_{2}$ at which the fish was exposed $\left(\mathrm{P}_{\mathrm{in}} \mathrm{O}_{2}\right.$ of $\left.10 \mathrm{~mm} \mathrm{Hg}\right)$ a significant reduction in $\mathrm{VO}_{2}$ values was observed. The $\mathrm{P}_{\mathrm{C}} \mathrm{O}_{2}$ for this group was about $16 \mathrm{~mm} \mathrm{Hg}$. The $\dot{\mathrm{V}} \mathrm{O}_{2}$ of the Mcys group decreased gradually and significantly below $60 \mathrm{~mm} \mathrm{Hg}$, and the $\mathrm{P}_{\mathrm{C}} \mathrm{O}_{2}$ was about $58 \mathrm{~mm} \mathrm{Hg}$. The $\dot{\mathrm{VO}}_{2}$ values of the Mcys group were significantly lower than that recorded for the Ctrl group in the $\mathrm{P}_{\text {in }} \mathrm{O}_{2}$ interval between 100 and $10 \mathrm{~mm} \mathrm{Hg}$.

The mean values of $\dot{V}_{\mathrm{G}}\left(\mathrm{mLH}_{2} \mathrm{O} \mathrm{kg}^{-1} \mathrm{~min}^{-1}\right), f_{\mathrm{R}}$ (breaths min ${ }^{-1}$ ) and $V_{\mathrm{T}}\left(\mathrm{mLH}_{2} \mathrm{O} \mathrm{kg}^{-1}\right.$ breath $\left.^{-1}\right)$ for both experimental groups during normoxia and graded hypoxia are presented in Fig. 2. The $\dot{V}_{\mathrm{G}}$ of the Ctrl group increased progressive and significantly above a $\mathrm{P}_{\mathrm{in}} \mathrm{O}_{2}$ of $60 \mathrm{~mm} \mathrm{Hg}$. The same tendency was recorded for the Mcys group, but with $\dot{V}_{\mathrm{G}}$ increases of lower magnitude. Significant

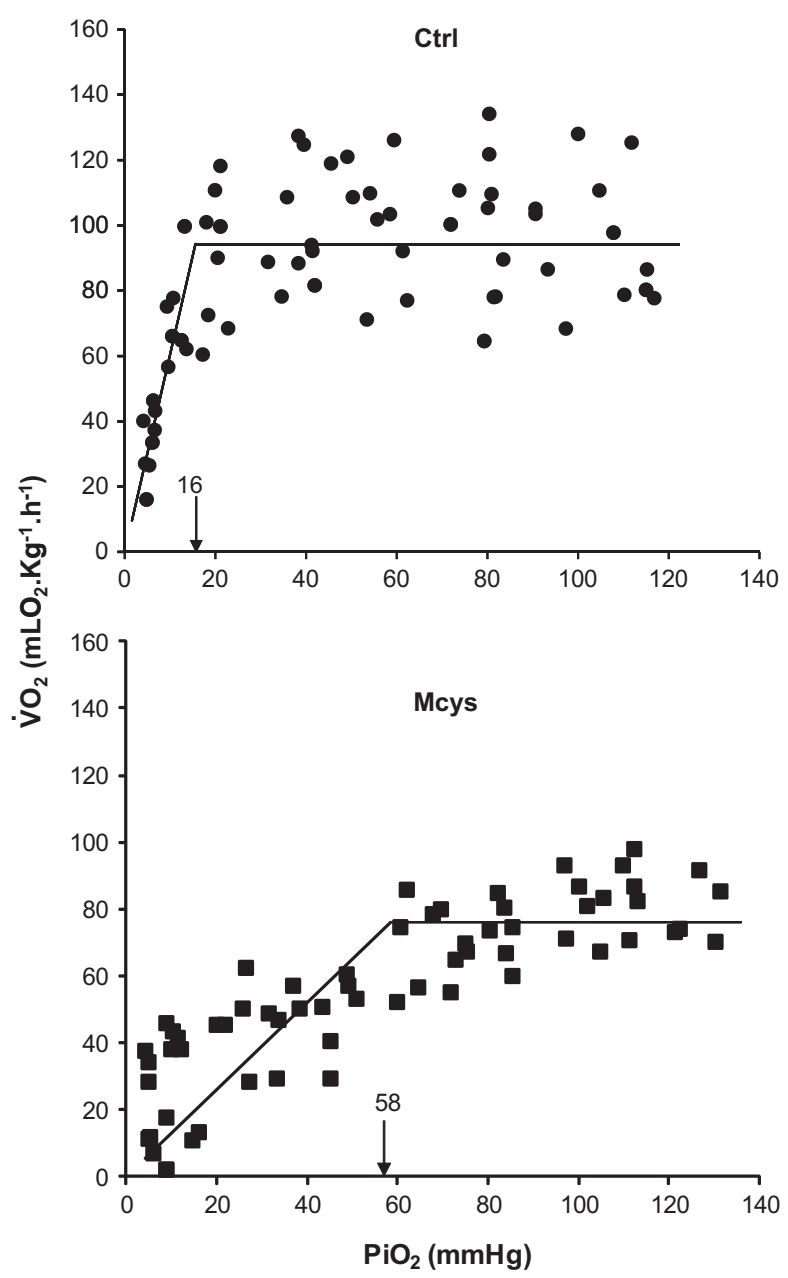

Fig. 1. Metabolic rate $\left(\mathrm{VO}_{2}\right)$ in relation to gradual reductions of $\mathrm{P}_{\mathrm{i}} \mathrm{O}_{2}(\mathrm{~mm} \mathrm{Hg})$ of control (Ctrl group, $n=8$ ) and MC-LR-exposed (Mcys group, $n=8$ ) Nile tilapia. The arrow indicates the critical oxygen tension $\left(\mathrm{P}_{\mathrm{c}} \mathrm{O}_{2}\right)$ in both groups. increases in the $f_{\mathrm{R}}$ values of the Ctrl group occurred only between 40 and $20 \mathrm{~mm} \mathrm{Hg}$, returning to initial values at $10 \mathrm{~mm} \mathrm{Hg}$ while the $f_{\mathrm{R}}$ of the Mcys group increased significantly at 20 and
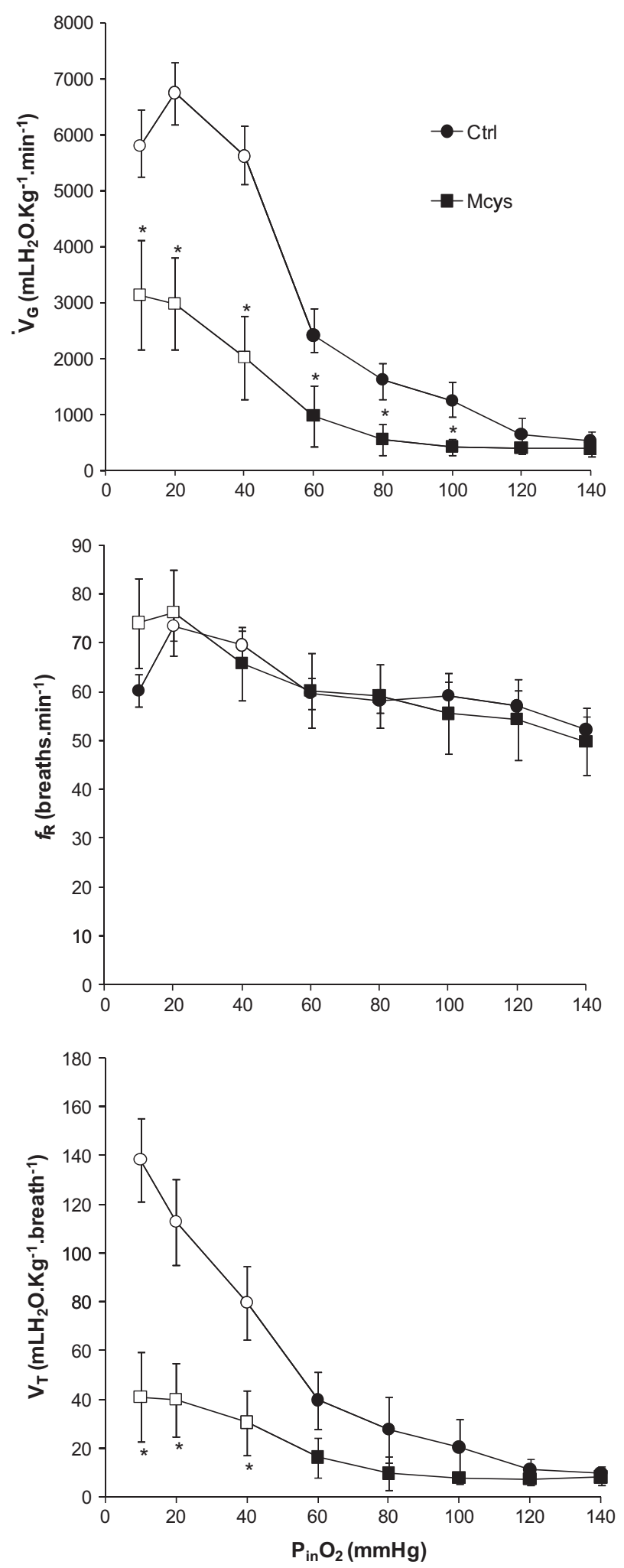

Fig. 2. The relationships between the ventilatory parameters $\left(\dot{V}_{\mathrm{G}}, f_{\mathrm{R}}\right.$, and $\left.V_{\mathrm{T}}\right)$ and the $\mathrm{P}_{\mathrm{in}} \mathrm{O}_{2}$ of control (Ctrl group, $n=8$ ) and MC-LR-exposed (Mcys group, $n=8$ ) Nile tilapia. Values are mean \pm SD. Open symbols indicate a significant difference in relation to the normoxic values, while asterisks indicate significant difference in relation to the control group $(p<0.05)$. 
$10 \mathrm{~mm} \mathrm{Hg}$. The $f_{\mathrm{R}}$ values of both groups did not show any significant difference. The reductions in the water $\mathrm{PO}_{2}$ caused significant increases in the $V_{\mathrm{T}}$ of both Ctrl and Mcys groups only below $60 \mathrm{~mm} \mathrm{Hg}$. However, the $V_{\mathrm{T}}$ values of the Ctrl group were significantly higher than those of the Mcys group in the $\mathrm{O}_{2}$ tensions between 40 and $10 \mathrm{~mm} \mathrm{Hg}$.

Fig. 3 presents the mean values for $\mathrm{O}_{2}$ extraction from the ventilatory current $\left(\mathrm{EO}_{2}\right)$ of the $\mathrm{Ctrl}$ and the Mcys groups in response to hypoxia. Both groups showed significant decreases of $\mathrm{EO}_{2}$ in $\mathrm{O}_{2}$ tensions below $80 \mathrm{~mm} \mathrm{Hg}$. The $\mathrm{EO}_{2}$ values of the Mcys group were significantly lower than the Ctrl ones only at 20 and $10 \mathrm{~mm} \mathrm{Hg}$.

The mean values of heart rate $\left(f_{\mathrm{H}}-\mathrm{bpm}\right)$ of both experimental groups are presented in Fig. 4. The Ctrl group maintained a constant $f_{\mathrm{H}}$ from normoxia to the $\mathrm{P}_{\mathrm{in}} \mathrm{O}_{2}$ of $20 \mathrm{~mm} \mathrm{Hg}$ and a significant bradycardia was recorded only at $10 \mathrm{~mm} \mathrm{Hg}$. For the Mcys group, $f_{\mathrm{H}}$ was kept constant form normoxia down to a $\mathrm{P}_{\mathrm{in}} \mathrm{O}_{2}$ of $40 \mathrm{~mm} \mathrm{Hg}$ below which $f_{\mathrm{H}}$ decreased progressively and significantly. The $f_{\mathrm{H}}$ values of the Mcys group were significantly lower than those obtained for the Ctrl group in all the experimental $\mathrm{O}_{2}$ tensions.

\section{Discussion}

When exposed to hypoxia, water-breathing fish usually trigger responses to maintain $\mathrm{VO}_{2}$ either by conserving energy expenditure or reducing energy turnover, and finally by anaerobic energy metabolism. Within a certain range of ambient $\mathrm{PO}_{2}$, fish are thus oxyregulators, but with further reductions in the $\mathrm{O}_{2}$ levels, $\dot{\mathrm{VO}}_{2}$ can no longer be maintained and they become oxyconformers. This species-specific value below which the oxygen requirements can no longer be met is often referred to as the critical oxygen tension, $\mathrm{P}_{\mathrm{C}} \mathrm{O}_{2}$. It represents a key parameter which, together with the fish $\dot{\mathrm{VO}}_{2}$, can be used to evaluate the ability of the fish to cope with oxygen limitation. This study reinforces previous findings of Fernandes and Rantin (1989) and Kalinin et al. (1999), showing that 0 . niloticus is an efficient oxyregulator, since $\dot{\mathrm{VO}}_{2}$ was maintained until the $\mathrm{P}_{\mathrm{c}} \mathrm{O}_{2}$ of $16 \mathrm{~mm} \mathrm{Hg}$ in the control group.

Exposure to MC-LR significantly increased $\mathrm{P}_{c} \mathrm{O}_{2}$ of $O$. niloticus to about $58 \mathrm{~mm} \mathrm{Hg}$ and the species become dependent of the environmental $\mathrm{PO}_{2}$ at higher tensions, reducing their capacity to survive hypoxic conditions.

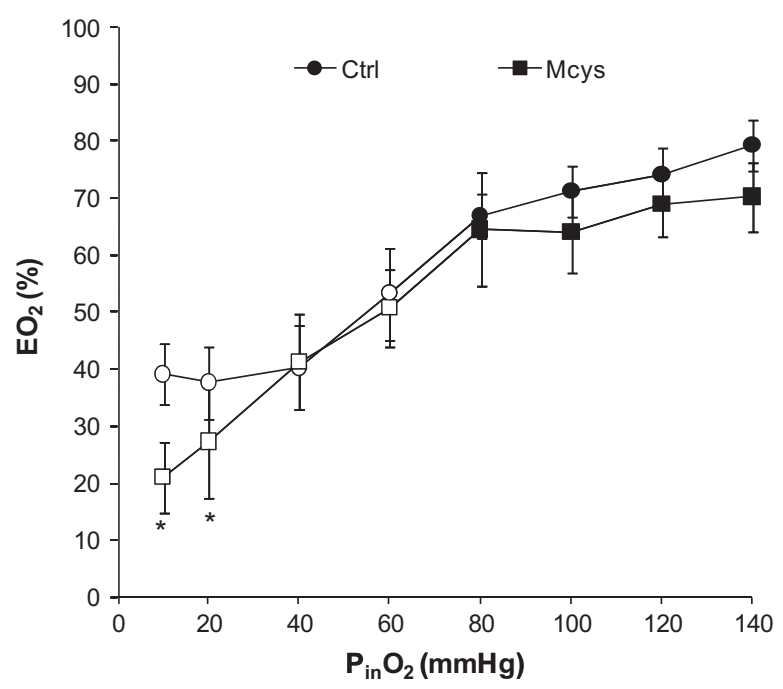

Fig. 3. The $\mathrm{O}_{2}$ extraction from the ventilatory current by the gills $\left(\mathrm{EO}_{2}\right)$ in relation to gradual reductions of $\mathrm{P}_{\mathrm{in}} \mathrm{O}_{2}(\mathrm{~mm} \mathrm{Hg})$ of control (Ctrl group, $\left.n=8\right)$ and MC-LRexposed (Mcys group, $n=8$ ) Nile tilapia. Values are mean \pm SD. Open symbols indicate a significant difference in relation to the normoxic values, while asterisks indicate significant difference in relation to the control group $(p<0.05)$.

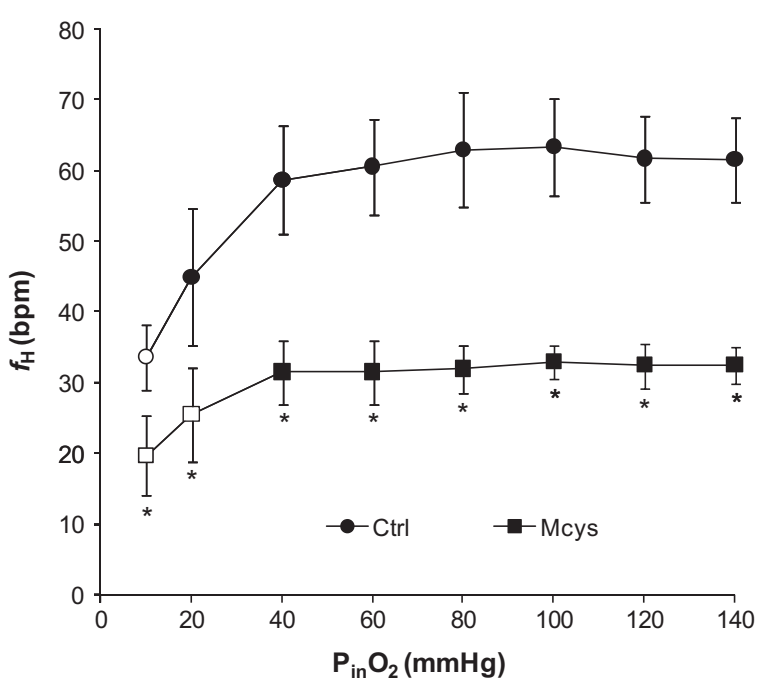

Fig. 4. The heart rate $\left(f_{\mathrm{H}}\right)$ in relation to gradual reductions of $\mathrm{P}_{\mathrm{in}} \mathrm{O}_{2}(\mathrm{~mm} \mathrm{Hg})$ of control (Ctrl group, $n=8$ ) and MC-LR-exposed (Mcys group, $n=8$ ) Nile tilapia. Values are mean \pm SD. Open symbols indicate a significant difference in relation to the normoxic values, while asterisks indicate significant difference in relation to the control group $(p<0.05)$.

The occurrence of cyanobacterial blooms is usually related to increased input of nutrients in the water (eutrophication) (Havens, 2007). In this context, one could expect that the combined eutrophication and cyanobacterial blooms would decrease water $\mathrm{PO}_{2}$, and thus, fish would be exposed to combined effects of microcystins and environmental hypoxia. Therefore, the fish ability to keep a constant metabolic rate and/or $\mathrm{P}_{\mathrm{C}} \mathrm{O}_{2}$ would be impaired, decreasing their chances of surviving in this environmental condition.

Prieto et al. (2006) reported significant increases in the activity of the antioxidant system of $O$. niloticus after exposure to MC-LR at a dose of $500 \mu \mathrm{g} \mathrm{kg}^{-1}$ body weight injected intraperitoneally. The authors observed lipid peroxidation in gills, liver and kidney. According to Davis (1975) and Steffensen (2006), when exposed to $\mathrm{O}_{2}$ tensions below its $\mathrm{P}_{\mathrm{C}} \mathrm{O}_{2}$, oxyregulators suffer reduction in their metabolic rate according to the decrease in environmental $\mathrm{PO}_{2}$. According to these authors, this is probably due to a gradual reduction in the efficiency of homeostatic mechanisms involved in $\mathrm{O}_{2}$ extraction by the gills and in the gas diffusion to tissues. The higher $\mathrm{P}_{\mathrm{C}} \mathrm{O}_{2}$ of the Mcys group indicates that the respiratory homeostasis was modified by this cyanotoxin, either in the $\mathrm{O}_{2}$ extraction or diffusion to the tissues, even at lower MC doses.

Changes in the respiratory homeostasis may be related to changes in blood oxygen capacity, probably due to a possible decrease in the hematocrit and hemoglobin concentration. Studies have demonstrated that microcystin can damage hematopoietic tissues of teleost fish such as spleen, liver and especially kidney (Quentel and Obach, 1992; Matushima, 1995), interfering with blood cell formation (Katharios et al., 2002; Zhang et al., 2007) and, consequently with $\mathrm{O}_{2}$ transport. As the kidneys are the most important hemogenic organs in fish (Ozaki, 1982), it is possible that intraperitoneal injection of MC-LR may have resulted in hypofunction of this organ which, allied to the damage occurring in the liver, caused anemia, which influenced the increase in $\mathrm{P}_{\mathrm{C}} \mathrm{O}_{2}$ recorded in the Mcys group. A similar scenario was described by Zhang et al. (2007) for the crucian carp, Carassius carassius, submitted to intraperitoneal injections of microcystin of 50 and $200 \mu \mathrm{g} \mathrm{kg}^{-1}$ body weight.

Increases in gill ventilation $\left(\dot{V}_{\mathrm{G}}\right)$ as the primary response to reduced environmental $\mathrm{O}_{2}$ tension has been observed in several fish species such as pacu, Piaractus mesopotamicus (Kalinin et al., 2000), 
trahira, Hoplias malabaricus, giant trahira, Hoplias lacerdae (Rantin et al., 1992), and common carp, Cyprinus carpio (Saunders, 1962; Lomholt and Johansen, 1979), among others. In this study, both experimental groups presented significant increases in $\dot{V}_{\mathrm{G}}$ during exposure to graded hypoxia. This hyperventilation was characterized by a larger increase in $V_{\mathrm{T}}$ than in $f_{\mathrm{R}}$. The predominance of this strategy has been documented for a number of teleost species (Smith and Jones, 1982; Fernandes and Rantin, 1989). According to Rantin et al. (1992), this mode of response may seem surprising, because fish posses a large potential for increase of respiratory frequency due to an often intermittent breathing pattern (Lomholt and Johansen, 1979). The motivation for this strategy could be a lower energy cost of the response, assuming that conservation of a constant velocity of muscular contraction is energy saving, whereas a higher frequency of contraction is limited by work against high internal viscosity of the muscle and a high viscosity of water (Rantin et al., 1992).

According to the "fundamental equation of respiratory physiology" proposed by Dejours (1981), $\left(\dot{V}_{\mathrm{G}} / \dot{\mathrm{VO}}_{2}\right) \cdot \mathrm{EO}_{2} \cdot \mathrm{P}_{\mathrm{in}} \mathrm{O}_{2}=1$, the maintenance of a constant metabolic rate when the environment $\mathrm{O}_{2}$ concentration declines is possible by means of an increase in $\dot{V}_{\mathrm{G}}$ and/or extraction in $\mathrm{EO}_{2}$. Due to the limited capacity of $\mathrm{EO}_{2}$ increases in fish, enhancements in $\dot{V}_{\mathrm{G}}$ are required to maintain a constant $\dot{\mathrm{VO}}_{2}$ (Kalinin et al., 1996). This statement implies that fish survival in hypoxic environments can be compromised if the ability to increase $\dot{V}_{\mathrm{G}}$ is affected. Therefore, although exhibiting a similar respiratory strategy during hypoxia, the Mcys group had significantly lower $\dot{V}_{\mathrm{G}}$ values when compared to the Ctrl, showing that exposures to MC-LR somehow impaired the normal respiratory responses in this group.

O. niloticus presents high values of $\mathrm{O}_{2}$ extraction $\left(\mathrm{EO}_{2}\right)$, in the range of $75-80 \%$ (Fernandes and Rantin, 1989; Kalinin et al., 1996). The increased $\dot{V}_{\mathrm{G}}$ while $\mathrm{EO}_{2}$ remains relatively high and constant is one of the most important respiratory compensations for reductions in environmental $\mathrm{O}_{2}$ (Fernandes and Rantin, 1989). The $\mathrm{EO}_{2}$ values of the Mcys group were significantly lower than the Ctrl ones in the more hypoxic tensions (20 and $10 \mathrm{~mm} \mathrm{Hg}$ ). Carbis et al. (1997) observed necrosis in gill cells of carp, C. carpio, exposed to blooms of cyanobacteria producing microcystin. Prieto et al. $(2006,2007)$ showed that exposure of $O$. niloticus to microcystin at sublethal doses $\left(500 \mu \mathrm{g} \mathrm{kg}^{-1}\right.$ body weight) caused oxidative stress and subsequent cellular destruction (lipid peroxidation) in various organs, including gills. An impairment of gill cells caused by lipid peroxidation could explain the reduced $\mathrm{EO}_{2}$ presented by the Mcys group during exposure to severe hypoxia in the present study.

Steffensen et al. (1982) argued that hypoxia-tolerant species exhibit a great potential to increase $\dot{V}_{G}$ with concomitant maintenance of $\mathrm{EO}_{2}$. In our study, both the ability to increase $\dot{V}_{\mathrm{G}}$ and maintain $\mathrm{EO}_{2}$ were impaired in the Mcys group, which reinforces the reduced survival chances in hypoxic environments.

Heart rate $\left(f_{\mathrm{H}}\right)$ have been used as an indicator of toxic effects of environmental contaminants in fish, and reductions in their values with concomitant increases in gill ventilation are common responses in fish exposed to a variety of xenobiotics (Heath, 1995; Teuschler et al., 2005). According to Farrell (1984), the reflex bradycardia produced by hypoxia can be valuable to ensure the performance of the heart during myocardial hypoxia. Therefore, the reduction in $f_{\mathrm{H}}$ of $O$. niloticus at $\mathrm{O}_{2}$ tensions near the $\mathrm{P}_{\mathrm{C}} \mathrm{O}_{2}$ probably preserved the energy expenditure of the heart when the $\mathrm{O}_{2}$ availability became reduced. Furthermore, bradycardia increases the residence time of blood within the ventricle, which could allow an increased extraction of $\mathrm{O}_{2}$ by the spongy myocardium. In the present study, the $f_{\mathrm{H}}$ values of the Mcys group were significantly lower than the $\mathrm{Ctrl}$ in all $\mathrm{O}_{2}$ tensions analyzed. In the Mcys group, a significant bradycardia appeared earlier, at $20 \mathrm{~mm} \mathrm{Hg}$, while in the Ctrl group a significant decrease in $f_{\mathrm{H}}$ occurred only at $10 \mathrm{~mm} \mathrm{Hg}$. Although both groups showed a similar bradycardic response to hypoxia, fish of the Mcys group presented significantly lower $f_{\mathrm{H}}$ values than those of the $\mathrm{Ctrl}$ group in all $\mathrm{O}_{2}$ tensions analyzed, indicating that MC-LR exposure affected the normal heart function of $O$. niloticus. Atencio et al. (2008), submitted specimens of $O$. niloticus to intraperitoneal injections of microcystin-LR (500 $\mu \mathrm{g} \mathrm{kg}^{-1}$ body weight) and, besides the injuries in organs such as liver and kidneys, they verified the occurrence of histopathology in the cardiac myocytes. Among these changes, myopathies with fibrolysis processes and generalized edema were observed in the cardiomyocytes due to a possible direct effect of MC-LR in the heart tissue. Accordingly, in the present study, a possible injury of heart tissue caused by MC-LR exposure could explain the reduced $f_{\mathrm{H}}$ and earlier bradycardia observed in the Mcys group, prejudicing the normal heart function.

\section{Conclusions}

Intraperitoneal injection of microcystin-LR(MC-LR - $100 \mu \mathrm{g} \mathrm{kg}^{-1}$ body weight) reduced the ability to increase $\dot{V}_{\mathrm{G}}$ and to maintain a constant $\dot{\mathrm{VO}}_{2}$ and $\mathrm{EO}_{2}$, impairing the maintenance of an adequate respiratory response to hypoxia. Moreover, MC-LR decreased $f_{\mathrm{H}}$ and anticipated the occurrence of hypoxic bradycardia, presumably due to damages in cardiac myocytes. Thus, exposure to MC-LR may reduce the survival chances of $O$. niloticus in hypoxic environments.

\section{Acknowledgments}

The authors are thankful to Águas Claras fish farm, which provided the fish. They are also grateful to Mr. José Roberto Sanchez and Mr. Angelo Carnelosi for the technical assistance. This study was funded by CAPES/Brazilian Ministry of Education (N.D. Martins fellowship), and National Council for the Development of Research and Technology (CNPq).

\section{References}

Amado, L.L., Monserrat, J.M., 2010. Oxidative stress generation by microcystins in aquatic animals: Why and how. Environ. Int. 36, 226-235.

Ariza, R.R., Keyse, S.M., Moggs, J.G., Wood, R.D., 1996. Reversible protein phosphorylation modulates nucleotide excision repair of damaged DNA by human cell extracts. Nucleic Acids Res. 24, 433-440.

Atencio, L., Moreno, I., Prieto, A.I., Moyano, R., Molina, A.M., Cameán, A.M., 2008 Acute effects of microcystins MC-LR and MC-RR on acid and alkaline phosphatase activities and pathological changes in intraperitoneally exposed tilapia fish (Oreochromis sp.). Toxicol. Pathol. 36, 449-458.

Best, J.H., Eddy, F.B., Codd, G.A., 2001. Effects of purified microcystin-LR and cell extracts of Microcystis strains PCC 7813 and CYA 43 on cardiac function in brown trout (Salmo trutta) alevins. Fish Physiol. Biochem. 24, 171-178.

Brownlee, E.F., Sellner, S.G., Sellner, K.G., 2005. Prorocentrum minimum blooms: potential impacts on dissolved oxygen and Chesapeake Bay oyster settlement and growth. Harm. Algae 4, 593-602.

Buryskova, B., Hilscherova, K., Babica, P., Vrskova, D., Marsalek, B., Blaha, L., 2006 Toxicity of complex cyanobacterial samples and their fractions in Xenopus laevis embryos and the role of microcystins. Aquat. Toxicol. 80, 346-354.

Carbis, C.R., Rawlin, G.T., Grant, P., Mitchell, G.F., Anderson, J.W., Maccauley, I., 1997. A study of feral carp Cyprinus carpio L., exposed to Microcystis aeruginosa at Lake Mokoan, Australia, and possible implication on fish health. J. Fish Dis. 20, 81-91.

Carmichael, W.W., 1994. The toxins of cyanobacteria. Sci. Am. 270, 78-86.

Chorus, I., Bartram, J., 1999. Toxic Cyanobacteria in Water: A Guide to Public Health Significance, Monitoring and Management. E \& FN Spon., London.

Davis, J.C., 1975. Minimal dissolved oxygen requirements of aquatic life with emphasis on Canadian species: a review. J. Fish. Res. Board Can. 32, 2295-2332.

De Figueiredo, D.R., Azeiteiro, U.M., Esteves, S.M., Goncalves, F.J.M., Pereira, J.M., 2004. Microcystin-producing blooms - a serious global public health issue. Ecotoxicol. Environ. Saf. 59, 151-163.

Dejours, P., 1981. Principles of Comparative Respiratory Physiology. Elsevier, New York.

Douglas, P., Moorhead, G.B., Ye, R., Lees-Miller, S.P., 2001. Protein phosphatases regulate DNA-dependent protein kinase activity. J. Biol. Chem. 276, 18992 18998. 
Eriksson, J.E., Grönberg, L., Nygard, S., Slotte, J.P., Meriluoto, J.A.O., 1990 Hepatocellular uptake of 3-H-dihydromicrocystin-LR, a cyclic peptide toxin Biochim. Biophys. Acta 1025, 60-66.

Farrell, A.P., 1984. A review of cardiac performance in the teleost heart: intrinsic and humoral regulation. Can. J. Zool. 62, 523-536.

Fastner, J., Codd, G.A., Metcalf, J.S., Woitke, P., Wiedner, C., Utkilen, H., 2002. An international intercomparison exercise for the determination of purified microcystin-LR and microcystins in cyanobacterial field material. Anal. Biochem. 374, 437-444.

Fernandes, M.N., Rantin, F.T., 1989. Respiratory responses of Oreochromis niloticus (Pisces, Cichlidae) to environmental hypoxia under different thermal conditions. J. Fish Biol. 35, 509-519.

Fischer, W.J., Dietrich, D.R., 2000. Pathological and biochemical characterization of microcystin-induced hepatopancreas and kidney damage in Carp (Cyprinus carpio). Toxicol. Appl. Pharmacol. 164, 73-81.

Guzman, R.E., Solter, P.F., Runnegar, M.T., 2003. Inhibition of nuclear protein phosphatase activity in mouse hepatocytes by the cyanobacterial toxin microcystin-LR. Toxicon 41, 773-781.

Havens, K.E., 2007. Cyanobacteria blooms: effects on aquatic ecosystems. In: Hudnell, H.K. (Ed.), Proceedings of the Interagency, International Symposium on Cyanobacterial Harmful Algal Blooms. Advances in Experimental Medicine \& Biology, pp. 745-759.

Heath, A.G., 1995. Water Pollution and Fish Physiology, second ed. Lewis Publishers, Boca Raton.

Hughes, G.M., Albers, C., Müster, D., Götz, K.H., 1983. Respiration of the carp, Cyprinus carpio L., at 10 and $20^{\circ} \mathrm{C}$ and the effects of hypoxia. J. Fish Biol. 22, 613-628.

Kalinin, A.L., Rantin, F.T., Fernandes, M.N., Glass, M.L., 1996. Ventilatory flow relative to intrabuccal and intraopercular volumes in two ecologically distinct erythrinids (Hoplias malabaricus and Hoplias lacerdae) exposed to normoxia and graded hypoxia. In: Val, A.L., Almeida-Val, V.M.F., Randall, D.J. (Eds.), Physiology and Biochemistry of the Fishes of the Amazon. INPA Ed., Manaus, pp. 191-202.

Kalinin, A.L., Glass, M.L., Rantin, F.T., 1999. A comparison of directly measured and estimated gill ventilation in the Nile tilapia, Oreochromis niloticus. Comp. Biochem. Physiol. 122, 207-211.

Kalinin, A.L., Severi, W., Guerra, C.D.R., Costa, M.J., Rantin, F.T., 2000. Ventilatory flow relative to intrabuccal and intraopercular volumes in the serrasalmid fish Piaractus mesopotamicus during normoxia and exposed to graded hypoxia. Rev. Bras. Biol. 60, 249-254.

Katharios, P., Georgudaki, J.I., Zoumbos, K.K., Spiropoulos, S., 2002. Toxicity of intraperitoneally injected ivermectin in sea bream, Sparus aurata. Fish Physiol. Biochem. 25, 99-108.

Kondo, F., Ito, Y., Oka, H., Yamada, S., Tsuji, K., Imokawa, M., Niimi, Y., Harada, K.I., Ueno, Y., Miyazaki, Y., 2002. Determination of microcystins in lake water using reusable immunoaffinity column. Toxicon 40, 893-899.

Lomholt, J.P., Johansen, K., 1979. Hypoxia acclimation in carp: how it affects oxygen uptake, ventilation and oxygen extraction from water. Physiol. Zool. 52, 38-49.

Malbrouck, C., Kestemont, P., 2006. Effects of microcystins on fish. Environ. Toxicol. Chem. 25, 72-86.

Matushima, E.R., 1995. Sistema linfóide em peixes. In: Santos, H.S.L. (Ed.), Histologia de peixes. FCAV-Unesp, Jaboticabal, pp. 44-45.

Ozaki, 1982. Fish Blood and Circulation Physiology. Science and Technology Press, Shanghai.
Prieto, A.I., Pichardo, S., Jós, A., Moreno, I., Cameán, A.M., 2006. Differential oxidative stress responses to microcystins LR and RR in intraperitoneally exposed tilapia fish (Oreochromis sp.). Aquat. Toxicol. 77, 314-321.

Prieto, A.I., Pichardo, S., Jós, A., Moreno, I., Cameán, A.M., 2007. Time-dependent oxidative stress responses after acute exposure to toxic cyanobacterial cells containing microcystins in tilapia fish (Oreochromis niloticus) under laboratory conditions. Aquat. Toxicol. 84, 337-345.

Prieto, A.I., Jós, A., Pichardo, S., Moreno, I., De Sotomayor, M.A., Moayano, R., Blanco, A. Caméan, A.M., 2009. Time-dependent protective efficacy of Trolox (vitamin E analog) against microcystin-induced toxicity in tilapia (Oreochromis niloticus). Environ. Toxicol. 24, 563-579.

Quentel, C., Obach, A. 1992. The cellular composition of the blood and haematopoietic organs of turbot Scophthalmus maximus L. J. Fish Biol. 41, 709-716.

Rantin, F.T., Kalinin, A.L., Glass, M.L., Fernandes, M.N., 1992. Respiratory responses to hypoxia in relation to mode of life in two erythrinid species (Hoplias malabaricus and Hoplias lacerdae). J. Fish Biol. 41, 805-812.

Reynolds, C.S., 1984. The Ecology of Freshwater Phytoplankton. Cambridge Univ. Press, Cambridge.

Saunders, R.L., 1962. The irrigation of the gills of fishes. II. Efficiency of oxygen uptake in relation to respiratory flow, activity and concentrations of oxygen and carbon dioxide. Can. J. Zool. 40, 817-862.

Smith, F.M., Jones, D.R., 1982. The effect of changes in blood oxygen carrying capacity on ventilation volume in the rainbow trout (Salmo gairdeneri). J. Exp. Biol. 97, 325-334.

Steffensen, J.F., 1989. Some errors in respirometry of aquatic breathers: how to avoid and correct for them. Fish Physiol. Biochem. 6, 49-59.

Steffensen, J.F., 2006. Oxygen consumption of fish exposed to hypoxia: Are they all oxyregulators or are any oxyconformers? Fish physiology, toxicology, and water quality. US Environmental Protection Agency. In: Proceedings of the Ninth International Symposium, Capri, Italy, pp. 239-250.

Steffensen, J.F., Lomholt, J.P., Johansen, K., 1982. Gill ventilation and $\mathrm{O}_{2}$ extraction during graded hypoxia in two ecologically distinct species of flatfish, the flounder (Platichthysflesus) and the plaice (Pleuronectesplatessa). Environ. Biol. Fish. 7, 157-163.

Teuschler, L.K., Gennings, C., Hartley, W.R., Carter, H., Thiyagarajah, A., Schoeny, R. Cubbison, C., 2005. The interaction effects of binary mixtures of benzene and toluene on the developing heart of medaka (Oryzias latipes). Chemosphere 58, 1283-1291.

Thomaz, J.M., Martins, N.D., Monteiro, D.A., Rantin, F.T., Kalinin, A.L. 2009. Cardiorespiratory function and oxidative stress biomarkers in Nile tilapia exposed to the organophosphate insecticide trichlorfon (NEGUVON). Ecotoxicol. Environ. Saf. 72, 1413-1424.

Toivola, D.M., Eriksson, J.E., 1999. Toxins affecting cell signaling and alteration of cytoskeletal structure. Toxicol. in Vitro 13, 521-530.

Zhang, X., Xie, P., Li, D., Shi, Z., 2007. Hematological and plasma biochemical responses of crucian carp (Carassius auratus) to intraperitoneal injection of extracted microcystins with the possible mechanisms of anemia. Toxicon 49 , 1150-1157.

Zhang, M., Wang, Z., Xu, Z., Liu, Y., Ni, L., Cao, T., Xie, P., 2011. Ammonium, microcystins, and hypoxia of blooms in eutrophic water cause oxidative stress and $\mathrm{C}-\mathrm{N}$ imbalance in submersed and floating-leaved aquatic plants in Lake Taihu, China. Chemosphere 82, 329-339. 